\title{
Performance of Front Line Demonstrations on Sesame (Sesamum indicum L.) in Karauli District of Rajasthan, India
}

\author{
Ramkishan Meena ${ }^{1 *}$, Bacchu Singh ${ }^{1}$, K.C. Meena ${ }^{2}$, R.K. Meena ${ }^{1}$, \\ B. Singh ${ }^{1}$ and Prakash Gurjar ${ }^{1}$ \\ ${ }^{1}$ Krishi Vigyan Kendra, Hindaun (Karauli), India \\ ${ }^{2}$ Krishi Vigyan Kendra, Swaimadhopur, India \\ *Corresponding author
}

\section{A B S T R A C T}

Sesamum indicum L., commonly known as sesame, is one of the oldest oilseed crops. Worldwide, it is used for its nutritional, medicinal, and industrial purposes. The sesame seed or its powder or its oil used in various Indian dishes as a flavoring agent. In India the

Keywords

Frontline

Demonstration,

Technology gap,

Extension gap,

Technology index

Article Info

Accepted:

12 February 2018

10 March 2018
Available Online: sesame crop can be cultivated as kharif, summer and also semi-rabi crop and 75 percent of sesame crop cultivated during the kharif season in India. One of the major constraints of traditional sesame farming is low productivity due to use local varieties and other factors. To replace this anomaly, Krishi Vigyan Kendra, Karauli has conducted frontline demonstration at adopted farmer's field. The results of FLDs shows that cultivation of high yielding variety of sesame (RT-351) recorded increase yield of 25.22, 12.00 and 23.63\% during kharif 2015, 2016 and 2017, respectively over local check. The technology gap which shows the gap in the demonstration yield over potential yield were 5.76, 6.50 and 6.80 q/ha for kharif 2015, 2016 and 2017, respectively. The highest extension gap of 1.30 was recorded in during kharif 2017 and this high extension gap requires urgent attention by the extension and development agencies. The technology index is 42.40, 35.0 and 32.0 percent during 2015, 2016 and 2017, respectively which shows the good performance. There is a need to adopt multi-pronged strategy that involves enhancing sesame production through area expansion and productivity improvements through better adoption of improved technology.

\section{Introduction}

Sesamum (Sesamum indicum L.) are flowering plants, which are cultivated in the tropical regions and is widely cultivated for the edible seeds its gives you. They are one of the oldest seeds which were cultivated over three thousand years ago. This seed can grow in the places, which are drought prone and the lands where other crops fail to grow, this seeds grows at its best. It has the maximum oil content and it is used as a very common ingredient in the foods all over the world. Sesame is called as queen of oilseeds crops by virtue of its excellent oil quality. It is having the highest oil content (46-64\%) and dietary energy $(6355 \mathrm{k} \mathrm{cal} / \mathrm{kg})$. It soil unlike other fats is highly stable and does not develop rancidity leading to loss of flavor and vitamin. India is the largest producer and exporter of sesame in 
the world (Puspha et al., 2003). The oilseeds scenario in the country has undergone a sea change. The main contributors to such transformation have been, i) availability of improved oil seeds production technology and its adoption, ii) expansion of cultivated area, iii) price support policy, iv) institutional support, particularly establishment of technology mission on oilseeds in 1986 (Hedge, 2004).

It is in oils that India is on shaky grounds (Chand, 2002). Inefficiencies in the oilprocessing sector are one reason; the other factor is the subsidy-driven ability of foreign producers to sell cheap oil. This finding indicates that oilseeds production in the country faces a threat due to inefficiency of processing and marketing and also due to transmission of volatility in world prices to the domestic market. In the medium term, accelerating import substitution, improving efficiency of the oil processing sector, and judicious use of tariffs are vital (Chand et al., 2004).

The improved technology packages were also found to be financially attractive. Yet, adoption levels for several components of the improved technology were low, emphasizing the need for better dissemination (Kiresur et al., 2001). Several biotic, abiotic and socioeconomic constraints inhibit exploitation of the yield potential and these needs to be addressed. The population of Karauli district dependent on agriculture and allied activities. The Bajra is the main crop grown in this area. The sesame crop is cultivated in kharif season from June to Sept. With the start of technology mission on oilseeds, frontline demonstration on sesame using new crop production technology was started with the objectives of showing the productive potentials of the new production technologies under real farm situation over the locally cultivated sesame crop.

\section{Materials and Methods}

The present investigation was carried out during the kharif season in the adopted villages under MGMG scheme of 'Krishi Vigyan Kendra of Karauli (Rajasthan). Materials and methods adopted for front line demonstration are given in table 1. Locally cultivated varieties were used as local check. The FLD was conducted to study the gaps between the potential yield and demonstration yield, extension gap and the technology index. In the present evaluation the data on output of sesame cultivation were collected from FLD plots, besides the data on local practices commonly adopted by the farmers of this region.

To estimate the technology gap, extension gap and the technology index the formulae are used (Samui et al., 2000).

Technology gap = Potential yield Demonstration yield

Extension gap $=$ Demonstration yield Farmers yield

(Potential yield - Demonstration yield)

Technology index = ---------------------- x 100

$$
\text { Potential yield }
$$

\section{Results and Discussion}

Frontline demonstrations were conducted on 80 hectares of land with 195 demonstration plots involving RT-351 sesame variety. On an average sesame variety RT-351 has given higher yield of 5.76, 6.50 and $6.80 \mathrm{q} / \mathrm{ha}$ in comparison with local variety during 2015, 2016 and 2017 respectively. The result indicates that the Frontline demonstration has given a good impact over the farming community of Karaulii as they were motivated by the new agricultural technologies applied in the FLD plots (Chand, 2002) (Table 2). 
Table.1 Existing farmer's practices and improved practices demonstrated in frontline demonstrations at farmer's field in Karauli, Rajasthan

\begin{tabular}{|c|c|c|c|}
\hline S. No. & Operations & Existing Farmer's Practices & $\begin{array}{l}\text { Improved/Recommended practices } \\
\text { adopted in demonstrated Plot (FLDs) }\end{array}$ \\
\hline 1. & Variety & Local & RT-351 \\
\hline 2. & Time of Sowing & June-July & June-July \\
\hline 3. & Seed treatment & Not done & $\begin{array}{l}\text { Carbendazim @ } \quad 2 \quad 2 \quad \mathrm{gm} \quad / \mathrm{Kg} \\
\text { seeds+Streptocycline } 2 \mathrm{gm} / \mathrm{Kg} \text { seeds and } \\
\text { PSB Culture @ } 5 \mathrm{gm} / \mathrm{Kg} \text { seeds }\end{array}$ \\
\hline 4. & Method of sowing & Broad casting & Line sowing \\
\hline 5. & $\begin{array}{ll}\text { Plant } & \text { Protection } \\
\text { Measures } & \end{array}$ & $\begin{array}{l}\text { Non-adoption of recommended } \\
\text { package of practices and } \\
\text { injudicious use of pesticides }\end{array}$ & $\begin{array}{l}\text { Thiram@2gm/Kg seed or Carbendazim @ } \\
1 \text { gm / Kg seed. + Metasystox } 25 \text { Ec @ } 1 \\
\mathrm{ml} / \text { lit water or spray with imidacloprid. }\end{array}$ \\
\hline
\end{tabular}

Table.2 Performance of front line demonstrations of sesame in Karauli, Rajasthan

\begin{tabular}{|l|c|c|c|c|c|c|c|c|c|c|c|}
\hline Year & $\begin{array}{c}\text { Area } \\
\text { (Ha) }\end{array}$ & $\begin{array}{c}\text { No. of } \\
\text { Demo. }\end{array}$ & \multicolumn{3}{|c|}{ Seed yield g/h } & $\begin{array}{c}\text { \% } \\
\text { increase } \\
\text { Over local }\end{array}$ & $\begin{array}{c}\text { Technol } \\
\text { ogy } \\
\text { Gap }\end{array}$ & $\begin{array}{c}\text { Extens } \\
\text { ion } \\
\text { Gap }\end{array}$ & $\begin{array}{c}\text { Technology } \\
\text { Index \% }\end{array}$ & \multicolumn{2}{|c|}{ B:C Ratio } \\
\hline Demo & $\begin{array}{c}\text { Local } \\
\text { check }\end{array}$ \\
\hline 2015 & 10 & 20 & 10 & 5.76 & 4.60 & 25.22 & 4.24 & 1.16 & 42.40 & 5.27 & 4.50 \\
\hline 2016 & 20 & 50 & 10 & 6.50 & 5.80 & 12.00 & 3.50 & 0.70 & 35.0 & 3.96 & 3.72 \\
\hline 2017 & 50 & 125 & 10 & 6.80 & 5.50 & 23.63 & 3.20 & 1.30 & 32.0 & 3.32 & 2.95 \\
\hline $\begin{array}{l}\text { Avera } \\
\text { ge }\end{array}$ & & & & $\mathbf{6 . 3 5}$ & $\mathbf{5 . 3 0}$ & 20.28 & $\mathbf{3 . 6 5}$ & $\mathbf{1 . 0 5}$ & $\mathbf{3 6 . 4 7}$ & $\mathbf{4 . 1 8}$ & $\mathbf{3 . 7 2}$ \\
\hline
\end{tabular}

\section{Diagnostic visit of farmer field by KVK, Scientists}

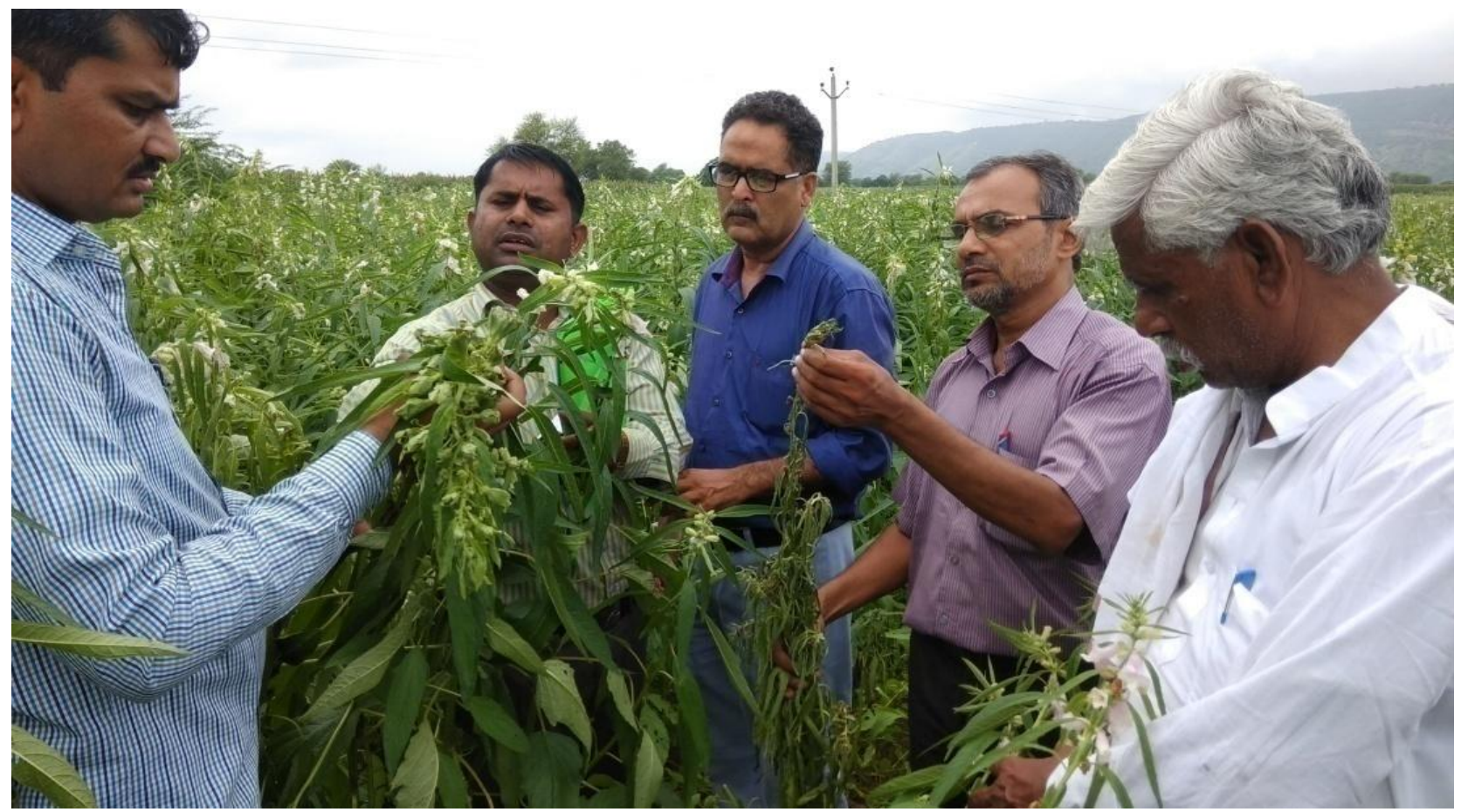




\section{Organized Field day at Farmers Field}

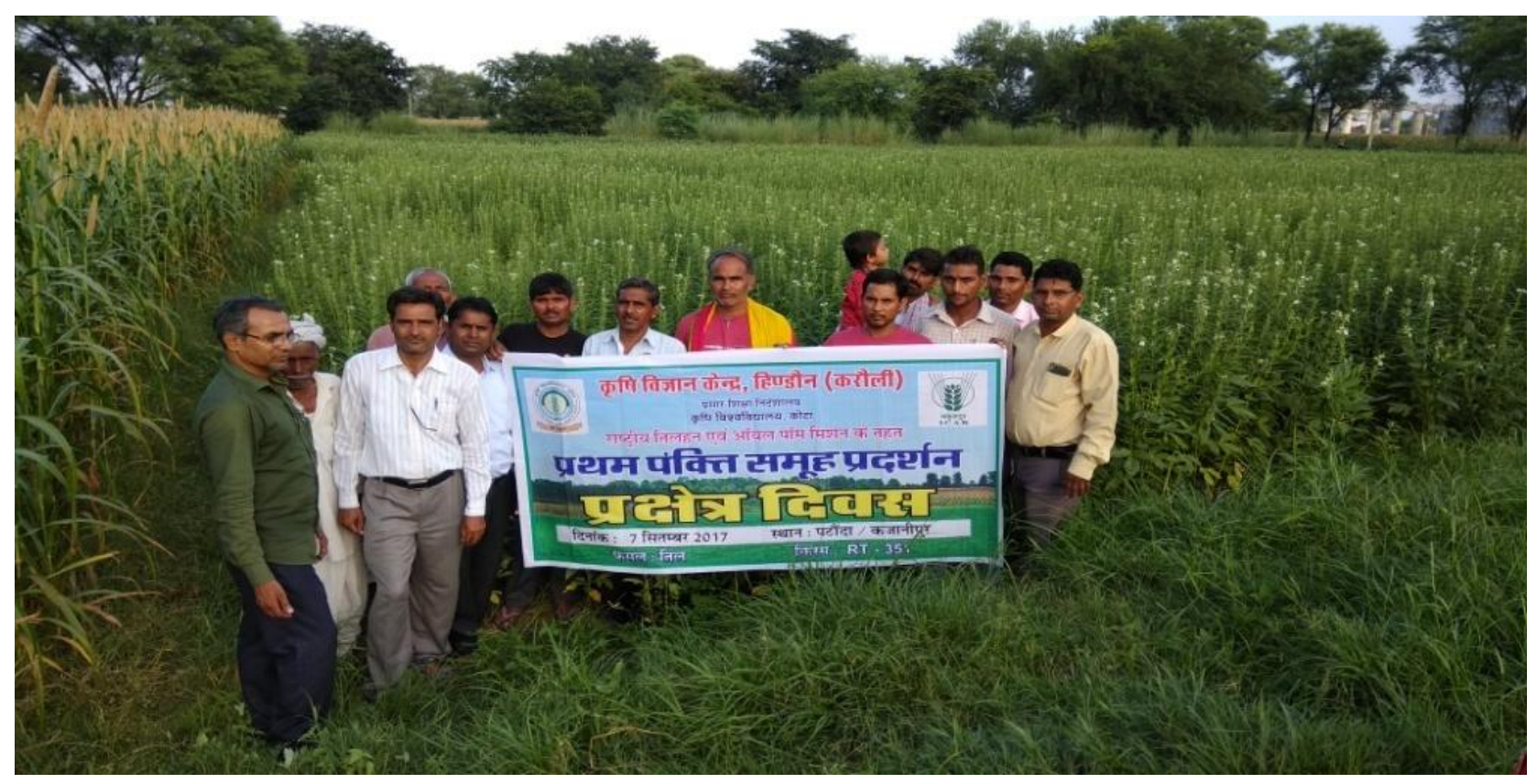

The yield of sesame was, however varied in different years, which might be due to the soil moisture availability and rainfall condition, climatic aberrations, disease and pest attacks as well as the change in the location of trials every year. The high yielding variety had performed extremely well when compared to local check. The percentage increase in the yield over local check was 25.22, 12.0, and 23.63 for during kharif 2015, 2016 and 2017, respectively and average increase in yield was 20.28 percent during study period. The technology gap which shows the gap in the demonstration yield over potential yield were 4.24, 3.50 and 3.20 during kharif 2015, 2016 and 2017, respectively and the average technology gap was found 3.65 during the study period. The technology gap observed may be attributed to dissimilarity in the soil fertility status and weather conditions. Hence location specific recommendation appears to be necessary to bridge the gap between the yields. The highest extension gap of 1.30 was recorded during 2017 which emphasized the need to educate the farmers through various means for the adoption of improved high yielding varieties and newly improved agricultural technologies to reverse this trend of wide extension gap. More and more use of new HYV's by the farmers will subsequently change this alarming trend of galloping extension gap (Hedge, 2004). The new technologies will eventually lead to the farmers to discontinuance of old varieties with the new technology. The technology index shows the feasibility of the evolved technology at the farmers' field. The lower the value of technology index more is the feasibility of the technology (Sagar and Chandra, 2004; Samui, 2000; Puspha and kiresur, 2001). The technology index is 42.40 , 35.0 and 32.0 per cent during kharif 2015, 2016 and 2017, respectively which shows the good performance of ICM in Karauli conditions and this will accelerate the adoption of newer technologies to increase the productivity of sesame in this area. These results are in conformity with the findings of Sagar and Ganesh Chandra (2004) and Anand Naik (2016). Despite the lower yield levels in Karauli areas, the newer technologies for production of sesame have given a very good 
result in comparison to local check. These practices may be popularized in this area by the extension agencies to mitigate the large extension gap. Mainly small and marginal farmers are associated with the cultivation and the use of new production technologies will substantially increase the income as well as the livelihood of the farming community. There is a need to adopt multipronged strategy that involves enhancing sesame production through area expansion and productivity improvements through better adoption of improved technology.

\section{References}

Anand Naik, Devappagouda H. Patil, Raju, G. Teggelli and Zaheer Ahamed, B.: Productivity enhancement of sesame (Sesamum indicum L.) through improved production technologies/ frontline demonstrations. Res. Environ. Life Sci. 9(5) 573-574 (2016).

Chand Raniesh Jha, D. and Mittal, S.: WTO and oilseed sector- Challenges of trade liberalization, economic and political weekly. p. 533-537 (2004).

Chand, Ramesh: Trade Liberalization, WTO an Indian Agriculture. Chapter4, Mittal Publ, New Delhi (2002).

Hedge, D.M.: Becoming self-reliant. Hindu survey of Indian agriculture. p. 45-47 (2004).

Kiresur, V.R, Rumana Rao, S.V. and Hedge, D.M. Improved Technologieson Oilseeds Production - An Assessment of their Economic potentials in India. Agric. Eco. Res. Rev., 14: 95-108 (2001).

Puspha, R. and Senthilkumar, P. Studies on the combining ability in Sesame ( $S$. indicum L.) Paper presented in the National Seminar on Advances in Genetics and Plant breeding Impact of DNA revolution. October 30-31, University of Agricultural Sciences, Dharwad, Karnauika, India (2003).

Sagar, R.L., and Ganesh Chandra: Front line demonstration on Sesame in West Bengal. Agricultural Extension Review, 10: 7-10 (2004).

Samui, S.K., Maitra, S., Roy, D.K., Mandal, A.K. and Saha, D.: Evaluation of Front Line demonstration on groundnut. J. Indian Soc. Coastal Agric. Res., 18: 180-183 (2000).

\section{How to cite this article:}

Ramkishan Meena, Bacchu Singh, K.C. Meena, R.K. Meena, B. Singh and Prakash Gurjar. 2018. Performance of Front Line Demonstrations on Sesame (Sesamum indicum L.) in Karauli District of Rajasthan. Int.J.Curr.Microbiol.App.Sci. 7(03): 1507-1511. doi: https://doi.org/10.20546/ijcmas.2018.703.179 